http://jmscr.igmpublication.org/home/ ISSN (e)-2347-176x ISSN (p) 2455-0450

crossref DOI: https://dx.doi.org/10.18535/jmscr/v8i1.76

Journal Of Medical Science And Clinical Research

\title{
Seropositivity of Hepatitis and Cancer Management-Review and Recommendations
}

\section{Prof. Subbiah Shanmugam1, Prof. Sujay Susikar ${ }^{2 *}$, Rajeswaran Ayyanar ${ }^{3}$}

${ }^{1}$ Professor\& Head of the Department, Department of Surgical Oncology, Government Royapettah Hospital, Chennai, India

${ }^{2}$ Associate Professor, Department of Surgical Oncology, Government Royapettah Hospital, Chennai, India

${ }^{3}$ Resident, Department of Surgical Oncology, Government Royapettah Hospital, Chennai, India

*Corresponding Author

Prof. Sujay Susikar

Associate Professor, Department of Surgical Oncology, Government Royapettah Hospital, Chennai, India

\begin{abstract}
Background: Hepatitis virus reactivation is one of the troublesome and preventable causes of mortality and morbidity in oncology patients. It causes significant morbidity either directly as liver injury or indirectly by delaying chemotherapy or definitive treatment. We started the research to find the cause of hepatitis virus (hepatitis $B \&$ hepatitis $C$ ) positivity, on subsequent admissions in patients who were previously negative by the same serological test. We conducted the research to find out the possible mode of acquisition of hepatitis virus

Objectives

1. To emphasize the importance of serological test during every admission particularly in a cancer ward and to standardize the protocol

2. Preventing hepatitis virus reactivation related morbidity and mortality.

3. To ensure safety of patients and medical personal.

4. To enhance safety during blood transfusion.

Materials and Methods: Patients admitted during the period of January2017 to March2019 in department of surgical oncology, government Royapettah hospital who were negative for hepatitis $B$ virus (HBV) Thepatitis $C$ virus (HCV) on first or initial admission and treated after that with blood transfusion, chemotherapy, interventional procedures were included. Patients who became positive on routine serology were reaffirmed by specific tests like ELISA, RNA/DNA tests. Along with that liver function test, radiological assessment of liver was done and morbidity and mortality recorded.

Results: Among the seroconverted patients, 60(68\%) were found to be positive for HBV and 26(29.5\%) were $H C V$ positive. Two patients were $(2.27 \%)$ positive for both $H B V \& H C V$. We found seroconversion in 38 patients. Female to male ratio was 1:0.9. In our study we found that $79 \%$ patients were between the age of 30 to 60 . We noted that $32(84.2 \%)$ patients with seroconversion was post chemotherapy. There were 11 patients $(28 \%)$ who got blood transfusion. In patients with seroconversion Adriamycin, CDDP, 5-FU based chemotherapy was used in 9,19,9 patients respectively. Musculoskeletal sarcoma and GIT cancers were most frequent among the seroconverted patients. During our hospital admissions 3 patients died of acute fulminant hepatic failure (mortality rate of 39 per 1000/year), 1 patient required ICU
\end{abstract}


admission and recovered. Half $(n=19)$ of patients having fibro scan above 12.5 kilopascals probably indicating that these patients were in a chronic hepatitis state.

Conclusion: In our study we frequently encountered patients who were seropositive after treatment. It was found to be related to chemotherapy induced immunosuppression causing hepatitis virus reactivation. We used rapid card test to detect $H B V$ and HCV antibody, which has very low sensitivity and not recommended for routine screening. Sensitivity and specificity of third generation EIA is $99 \%$ and is recommended for routine screening (32).

As an oncologist it is important to be aware about this potential life threatening and treatable condition. Timely administration of antiviral prophylaxis will reduce the viral reactivation related fulminant hepatic failure and death.

1. The serological tests recommended to detect $H B V$, in descending order are $H B V$-DNA, $H B$ s $A g$ and $\mathrm{HB}$ e $\mathrm{Ag}$

2. For HCV it is ideal to do HCV antibody as a screening test, followed by EIA and HCV RNA as a confirmative test.

Keywords: Hepatitis, $H B V$ and HCV reactivation, chemotherapy induced hepatitis virus reactivation.

\section{Introduction}

Hepatitis virus reactivation is one of the troublesome and preventable causes of mortality and morbidity in oncology patients. It causes significant morbidity either directly as liver injury or indirectly by delaying chemotherapy or definitive treatment. We started the research to find the cause of hepatitis virus (hepatitis B \& hepatitis C) positivity, on subsequent admissions in patients, who were previously negative by the same serological test. We conducted the research to find out the possible mode of acquisition of hepatitis virus. We tried to detect the possibility of association with blood transfusion, chemotherapy related reactivation or getting infected during admission from others. It is imperative to know the hepatitis viral status for the safety of patients and medical personals. Acquiring viral transmission or reactivation during hospital admission despite all precautions cannot be underestimated.

The objectives of the study were

1. To emphasize the importance of serological test during every admission particularly in a cancer ward and to standardize the protocol

2. Preventing hepatitis virus reactivation related morbidity and mortality.

3. To ensure safety of patients and medical personal.
4. To enhance safety during blood transfusion.

\section{Materials and Methods}

Patients admitted during the period of January 2017 to March 2019 in department of surgical oncology, government Royapettah hospital who were negative for hepatitis $B$ virus (HBV) /hepatitis C virus (HCV) on first or initial admission and treated after that with blood transfusion, chemotherapy, interventional procedures were included. Patients who became positive on routine serology were reaffirmed by specific tests like ELISA, RNA/DNA tests. Along with that liver function test, radiological assessment of liver was done and morbidity and mortality recorded. All patients with hepatitis were treated in medical gastroenterology (MGE) / hepatology department and the response to treatment was recorded. All the parameters were analyzed by standard statistical methods.

\section{Results}

Among 4770 admissions during the study period (January 2017 to March 2019) total 88(incidence $=1.84 \%$ ) patients were found to be either HBV or $\mathrm{HCV}$ positive. Among these patients 60(68\%) were found to be positive for HBV and $26(29.5 \%)$ were $\mathrm{HCV}$ positive and 2 patients were $(2.27 \%)$ positive for both $\mathrm{HBV} \& \mathrm{HCV}$. 
We found seroconversion (positive on subsequent admissions by same serology) in 38 patients. Female to male ratio was 1:0.9

Table-1 depicting the frequency of hepatitis virus positivity among seroconversion.

Table-1. Abstract of positivity.

\begin{tabular}{|l|c|}
\hline HBV & 19 \\
\hline HCV & 17 \\
\hline HBV\&HCV & 2 \\
\hline
\end{tabular}

\section{Table-2}

\begin{tabular}{|l|c|c|c|c|}
\hline & HBV & HCV & HBV\&HCV & Total \\
\hline Seroconversion & 19 & 17 & 2 & 38 \\
\hline Age & & & & \\
12-30yrs & 3 & 1 & 0 & 4 \\
30-60yrs & 16 & 13 & 1 & 30 \\
$>$ 60yrs & 0 & 3 & 1 & 4 \\
\hline Gender & 7 & 10 & 1 & 18 \\
Male & 12 & 7 & 1 & 20 \\
Female & & & & \\
\hline Chemotherapy & 17 & 13 & 2 & 32 \\
Yes & 2 & 4 & 0 & 6 \\
No & & & & \\
\hline Blood transfusion & 6 & 4 & 1 & 11 \\
Yes & 13 & 13 & 1 & 27 \\
No & & &
\end{tabular}

In our study we found that $79 \%$ patients were present between ages of 30 to 60 . HBV was positive in $10.5 \%$ in patients with $<30$ years of age. HCV positivity was noted in $10.5 \%$ patients with age $>60$ years. There was no significant gender difference in seroconversion incidence and there was more incidence of HBV among females and $\mathrm{HCV}$ among males. We found that 32 patients with seroconversion (84.2\%) were post chemotherapy. There were 11 patients $(28 \%)$ who got blood transfusion.

Table-3 Mode of treatment proceeding serocoversion

\begin{tabular}{|l|c|c|c|}
\hline & HBV & HCV & $\begin{array}{c}\text { HBV \& } \\
\text { HCV }\end{array}$ \\
\hline Chemo therapy only & 4 & 4 & 0 \\
\hline Chemo radiation & 6 & 5 & 1 \\
\hline Blood transfusion+ surgery & 0 & 1 & 0 \\
\hline Blood +chemo radiation & 4 & 0 & 0 \\
\hline Radiation +surgery & 0 & 1 & 0 \\
\hline Surgery only & 2 & 2 & 0 \\
\hline $\begin{array}{l}\text { Blood transfusion } \\
\text { chemotherapy }\end{array}$ & 2 & 3 & 1 \\
\hline Chemo radiation + surgery & 1 & 1 & 0 \\
\hline
\end{tabular}

Table-4 Type of cancer associated with seroconversion and reactivation

\begin{tabular}{|l|c|c|c|c|c|c|c|c|c|}
\hline Primary & STS \&bone & gynac & breast & GIT & Skin & GUT & multiple & H\&N & parathyroid \\
\hline number & 9 & 6 & 4 & 9 & 1 & 3 & 1 & 5 & 1 \\
\hline
\end{tabular}

In patients with seroconversion Adriamycin, CDDP, 5-FU based chemotherapy was used in 9,19,9 patients respectively. Musculoskeletal sarcoma and GIT cancers were most frequent among the seroconverted patients followed by gynecological and head \& neck cancers. 90\% reactivation occurs within 3 to 6 months after chemotherapy. Three patients died of acute fulminant hepatic failure (mortality rate of 39 per 1000/year), 1 patient required ICU admission and recovered.

Liver stiffness, as measured by transient elastography during USG abdomen, is a surrogate marker for cirrhosis in hepatitis virus positive patients. A liver stiffness value below 7.1 kilopascals $(\mathrm{kPa})$ rules out significant liver fibrosis, where as a liver stiffness value above $12.5 \mathrm{kPa}$ is predictive of cirrhosis. Between these thresholds, the liver stiffness value is inconclusive. In our study we found that $12(31 \%)$ patients were below $7.1 \mathrm{KPa}$ and 4 patients were 7.1 to $12.5 \mathrm{KPa}$, and $50 \%(\mathrm{n}=19)$ of patients having fibro scan above 12.5 kilopascals probably indicating that these patients were in chronic hepatitis state.

In our study 2 patients who underwent surgery without blood transfusion or chemotherapy or chemo radiation were among the seroconverted.

\section{Discussion}

There are four phases of HBV infection interaction between the virus and the host immune system

1. Immune tolerance

2. immune clearance

3. Immune control

4. Immune escape 
Mechanism of liver injury in $\mathrm{HBV}$ reactivation

Liver injury due to $\mathrm{HBV}$ reactivation associated with immunosuppression due to chemotherapy occurs by 2 mechanisms.

1. Uncontrolled viral replication during immunosuppression causes direct cytolytic destruction of hepatocytes. After chemotherapy or immunosuppression has been ceased, immune reconstitution may cause severe immune mediated injury to infected hepatocytes

2. An elevated/enhanced immune response against hepatocytes expressing viral proteins- causing necrosis of liver cells.

The delayed reactivation associated with immune reconstitution may occur up to six months after cessation of immunosuppression ${ }^{(1,2)}$. HBV reactivation due to chemotherapy induced immunosuppression can result in asymptomatic biochemical hepatitis, acute symptomatic hepatitis may lead to fulminant liver failure and death ${ }^{(3)}$.

\section{HBsAg negative, anti-HBc positive patients}

Clearance of HBsAg occurs at a rate of $0.5 \%$ per year in patients with previously diagnosed chronic hepatitis $\mathrm{B}(\mathrm{CHB})^{(4)}$. Individuals may have serological evidence of past HBV exposure, both scenarios leads to an HBsAg negative/hepatitis B core antibody (anti-HBc) positive state. These patients remain at risk of $\mathrm{HBV}$ reactivation due to immunosuppression due to the persistence of the $\mathrm{HBV}$ in the form of cccDNA in hepatocytes and other tissues $^{(5,6)}$.

Anti-HBs may not be detectable during a window period of several weeks to months after the disappearance of HBsAg. During this period, the diagnosis of acute $\mathrm{HBV}$ infection is made by the detection of IgM anti-HBc in serum. IgM anti$\mathrm{HBc}$ may become detectable during exacerbations of chronic hepatitis B and is often used as a surrogate for active viral replication. Anti-HBc of the IgG class is found in persons who recover from acute hepatitis B and also is the form found in those who progress to chronic infection.
Tests for HBV

Table-5 serologic tests and inference

\begin{tabular}{|l|l|}
\hline Marker /tests & Inference \\
\hline Anti-HBs & Prior infection or vaccination \\
\hline IgM anti HBc & Window period \\
\hline Anti HBc & Acute \& chronic infection \\
\hline IgG anti-HBc & $\begin{array}{l}\text { Recovery phase or progress to } \\
\text { chronic infection }\end{array}$ \\
\hline
\end{tabular}

As per American Gastroenterology Association guidelines on the prevention and treatment of hepatitis B reactivation during immunosuppressive drug therapy, the risk estimate is more than $10 \%$ when Adriamycin based chemo therapy $(7,8)$. In our study, besides Adriamycin, CDDP and Paclitaxel also been associated with reactivation.

\section{HCV associated seroconversion}

Worldwide estimates of the prevalence of $\mathrm{HCV}$ antibodies, range from $1.6 \%$ to $2.8 \%(10,24)$. The highest prevalence is reported in low-income countries, including Egypt (15\%), Pakistan (4.7\%), and Taiwan (4.4\%),21 and is lower in North America (range, 1.1\%-1.3\%), Australia $(1.7 \%)$, and Eastern and Western Europe (range, $0.5 \%-4.5 \%)^{(9)}$. The latest epidemiologic reports suggest that there are currently 80 million HCVRNA-positive individuals around the globe. ${ }^{(24,27)}$ Chronic hepatitis virus which affects millions of patients $^{(11)}$. Negative findings on screening for $\mathrm{HCV}$ antibodies with detectable HCV RNA will leads to serum False-negative results.

Among patients with cancer receiving chemotherapy, liver dysfunction caused by hepatitis $\mathrm{B}$ virus (HBV) reactivation is a significant problem, ${ }^{(13,14)}$ occurring in $14 \%$ to $72 \%$ of patients who did not receive prophylactic antiviral therapy, leading to liver failure in $13 \%$ of cases and death in $6 \%$ of cases $^{(13,14,20,21)}$. We also found that 3 patients died of HBV without anti viral prophylaxis and no mortality reported among $\mathrm{HCV}$ infected individual. 


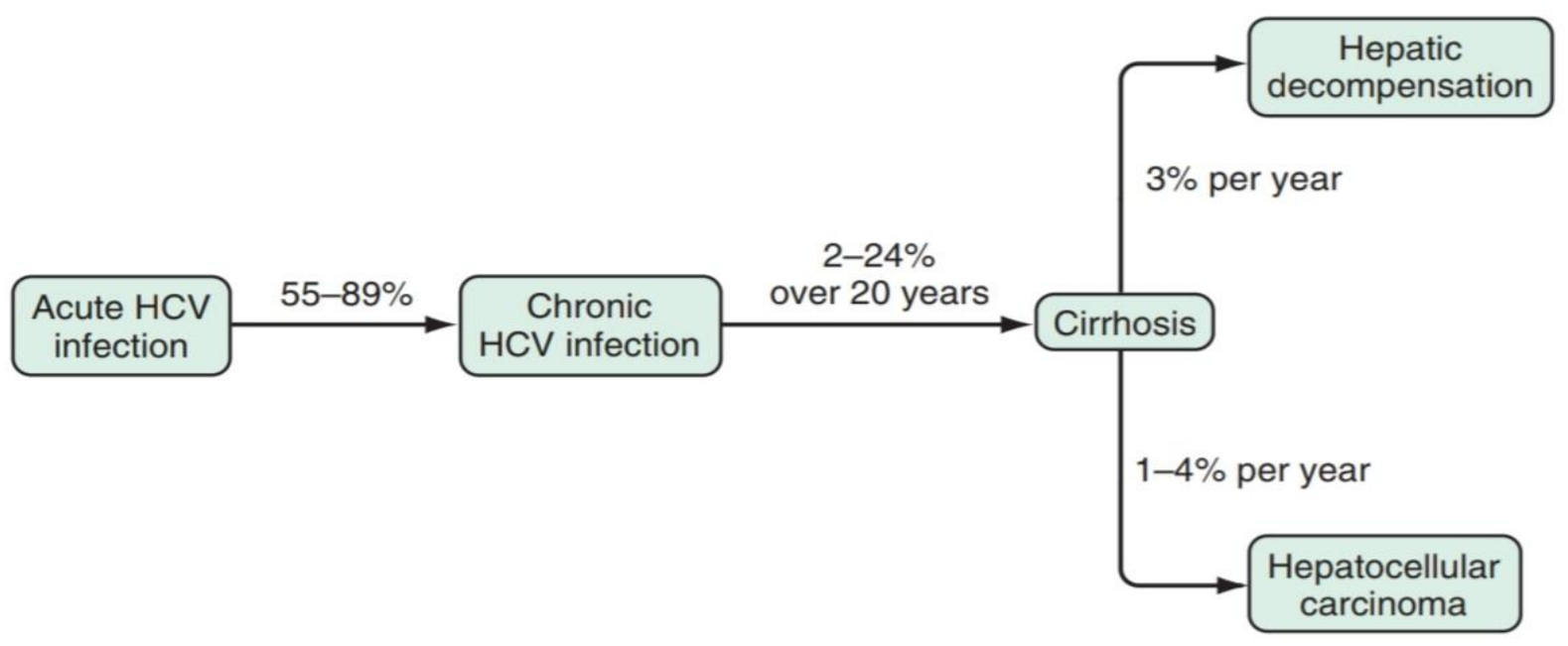

\section{Tests for HCV}

\begin{tabular}{|l|c|c|c|}
\hline Assays & Test type & Value & Inference \\
\hline Serological -indirect & $\begin{array}{c}\text { EIA(enzyme } \\
\text { immune assay) }\end{array}$ & Ratio $>9$ & Prior infection \\
\hline Serological -indirect & $3^{\text {rd }}$ generation- EIA & $\begin{array}{c}\text { Detect antibodies-against } \\
\text { NS3,4,5 and HCV core antibody }\end{array}$ & $\begin{array}{c}7-8 \text { weeks after infection - } \\
\text { sensitivity and specificity 99\%(32) }\end{array}$ \\
\hline Virological -direct & HCV RNA & $10-15$ IU/ml & Quantitative \\
\hline Virological -direct & HCV core Antigen & $\begin{array}{c}\text { Cheaper alternative to HCV } \\
\text { RNA }\end{array}$ & Confirm HCV viremia \\
\hline
\end{tabular}

Direct assays like HCV RNA tests represent the state of art for determining HCV viremia in anti HCV positive patients ${ }^{(33)}$. Serological assays are used initially for diagnosis; virological assays are required for confirming infection, monitoring response to treatment, and evaluating immunocompromised patients. A cheaper and faster alternative to nucleic acid testing for $\mathrm{HCV}$ RNA to confirm HCV viremia is the $\mathrm{HCV}$ core antigens assay.

In contrast, the incidence and consequences of $\mathrm{HCV}$ reactivation $(\mathrm{HCVr})$ during cancer treatment remain poorly defined. $\mathrm{HCVr}$ appears to be less common and to have less severe consequences than HBV reactivation, ${ }^{(12,14,15,17,18)}$ with only a few fatal cases of fulminant hepatitis attributed to HCV having been reported ${ }^{(18,19)}$.

The management of chronic $\mathrm{HCV}$ infection has been neglected in many cancer centers, likely due to treating patients concomitantly with chemotherapy and older HCV therapy, such as interferon $^{(28)}$. In current scenario direct-acting antiviral (DAAs) have changed the treatment paradigm for chronic $\mathrm{HCV}$ infection and improved virologic outcomes, even in $\mathrm{HCV}$ infected patients with cancer ${ }^{(29,}{ }^{30)}$. In some regions of Europe and Asia, HCV antibodies have been reported in up to $2.8 \%$ of patients with solid tumors $^{(31)}$. For screening HCV antibodies and to confirm HCV RNA is widely used and approved by US-FDA.

\section{Conclusion}

In our study we frequently encountered patients who were seropositive after institution of treatment. It was found to be related to chemotherapy induced immunosuppression causing hepatitis virus reactivation.

We used rapid card test to detect HBV and HCV antibody, which has very low sensitivity and not recommended for routine screening. The sensitivity and specificity of third generation EIA is $99 \%$ and is recommended for routine screening (32).

As an oncologist it is important to be aware about this potential life threatening and treatable 
condition. Timely administration of antiviral prophylaxis will reduce the viral reactivation related fulminant hepatic failure and death.

The serological tests recommended to detect $\mathrm{HBV}$, in descending order are HBV-DNA, HBs $\mathrm{Ag}$ and $\mathrm{HB}$ e $\mathrm{Ag}$

For $\mathrm{HCV}$ it is ideal to do HCV antibody as a screening test by EIA and HCV RNA as a confirmative test

Along with above mentioned tests the following may be recommended

1. All patients are to be screened by third generation EIA and card test is not to be used as standard method of screening.

2. Proper sterilization

3. Prior vaccination for high risk patients and all medical and paramedical staffs against HBV.

4. All cancer patients to be evaluated with liver function tests.

5. All hepatitis seropositive patients who are planned for chemotherapy should be given under cover of antiviral treatment especially for HBV.

\section{Limitations of the study}

It is retrospective study with a small sample size, card test was used to find $\mathrm{HBV} / \mathrm{HCV}$ which does not reflect the true incidence and prevalence in our study.

\section{Bibliography}

1. Dai MS, Chao TY, Kao WY, Shyu RY, Liu TM. Delayed hepatitis B 231 Venessa Pattullo. HBV reactivation with immunosuppression virus reactivation after cessation of preemptive lamivudine in lymphoma patients treated with rituximab plus CHOP. Ann Hematol 2004;83:769-774.

2. Hsu C, Hsiung CA, Su IJ, Hwang WS, Wang MC, Lin SF, et al. A revisit of prophylactic lamivudine for chemotherapy-associated hepatitis B reactivation in non-Hodgkin's lymphoma: a randomized trial. Hepatology 2008;47:844-853.

3. Lok AS, Liang RH, Chiu EK, Wong KL, Chan TK, Todd D. Reactivation of hepatitis B virus replication in patients receiving cytotoxic therapy. Report of a prospective study. Gastroenterology 1991;100:182-188.

4. Liaw YF, Sheen IS, Chen TJ, Chu CM, Pao CC. Incidence, determinants and significance of delayed clearance of serum HBsAg in chronic hepatitis $B$ virus infection: a prospective study. Hepatology 1991;13:627-631.

5. Bréchot C, Degos F, Lugassy C, Thiers V, Zafrani S, Franco D, et al. Hepatitis B virus DNA in patients with chronic liver disease and negative tests for hepatitis $\mathrm{B}$ surface antigen. $\mathrm{N}$ Engl $\mathrm{J}$ Med 1985;312:270-276.

6. Chemin I, Jeantet D, Kay A, Trépo C. Role of silent hepatitis B virus in chronic hepatitis B surface antigen(-) liver disease. Antiviral Res 2001;52:117-123.

7. Perrillo RP, Gish R, Falck-Ytter YT. American gastroenterological association institute technical review on prevention and treatment of hepatitis $B$ virus reactivation during immunosuppressive drug 235 enessa Pattullo.HBV reactivation with immunosuppression http://www.ecmh.org http://dx.doi.org/10.3350/cmh.2016.0024 therapy. Gastroenterology 2015;148:221244 e3.

8. Reddy KR, Beavers KL, Hammond SP, Lim JK, Falck-Ytter YT. American gastroenterological association institute guideline on the prevention and treatment of hepatitis B virus reactivation during immunosuppressive drug therapy. Gastroenterology 2015;148:215- 219.

9. Gower E, Estes C, Blach S, RazaviShearer K, Razavi H. Global epidemiology and genotype distribution of 
the hepatitis C virus infection. J Hepatol. 2014;61(suppl 1):S45-S57.

10. Mohd Hanafiah K, Groeger J, Flaxman AD, Wiersma ST. Global epidemiology of hepatitis $\mathrm{C}$ virus infection: new estimates of age-specific antibody to $\mathrm{HCV}$ seroprevalence. Hepatology. 2013;57: 1333-1342.

11. Reddy KR, Beavers KL, Hammond SP, Lim JK, Falck-Ytter YT. American gastroenterological association institute guideline on the prevention and treatment of hepatitis B virus reactivation during immunosuppressive drug therapy. Gastroenterology 2015;148:215- 219.

12. .Markovic S, Drozina G, Vovk M, FidlerJenko M. Reactivation of hepatitis B but not hepatitis $C$ in patients with malignant lymphoma and immunosuppressive therapy. A prospective study in 305 patients. Hepatogastroenterology 1999;46:2925-2930.

13. Torres HA, Davila M. Reactivation of hepatitis B virus and hepatitis C virus in patients with cancer. Nat Rev Clin Oncol 2012; 9:156-166.

14. Vento S, Cainelli F, Longhi MS. Reactivation of replication of hepatitis $B$ and $\mathrm{C}$ viruses after immunosuppressive therapy: an unresolved issue. Lancet Oncol 2002;3:333-340.

15. Lok AS, Ward JW, Perrillo RP, McMahon BJ, Liang TJ. Reactivation of hepatitis B during immunosuppressive therapy: potentially fatal yet preventable. Ann Intern Med 2012;156:743-745.

16. Mahale P, Kontoyiannis DP, Chemaly RF, Jiang Y, Hwang JP, Davila M, et al. Acute exacerbation and reactivation of chronic hepatitis $\mathrm{C}$ virus infection in cancer patients. J Hepatol 2012;57: 1177-1185.

17. Fujii Y, Kaku K, Tanaka M, Yosizaki M, Kaneko T, Matumoto N. Hepatitis C virus infection in patients with leukemia. Am J Hematol 1994;46:278-282.
18. Zuckerman E, Zuckerman T, Douer D, Qian D, Levine AM. Liver dysfunction in patients infected with hepatitis $\mathrm{C}$ virus undergoing chemotherapy for hematologic malignancies. Cancer1998;83:1224-1230.

19. Vento S, Cainelli F, Mirandola F, Cosco L, Di Perri G, Solbiati M, et al. Fulminant hepatitis on withdrawal of chemotherapy in carriers of hepatitis C virus. Lancet 1996;347:92-93.

20. Evans AT, Loeb KR, Shulman HM, Hassan S, Qiu WC, Hockenbery DM, et al. Fibrosing cholestatic hepatitis $\mathrm{C}$ after hematopoietic cell transplantation: report of 3 fatal cases. Am J Surg Pathol 2015;39:212-220.

21. Lok AS, Ward JW, Perrillo RP, McMahon BJ, Liang TJ. Reactivation of hepatitis B during immunosuppressive therapy: potentially fatal yet preventable. Ann Intern Med 2012;156:743-745.

22. Lok AS, Liang RH, Chiu EK, Wong KL, Chan TK, Todd D. Reactivation of hepatitis B virus replication in patients receiving cytotoxic therapy. Report of a prospective study. Gastroenterology 1991;100:182-188.

23. Loomba R, Rowley A, Wesley R, Liang TJ, Hoofnagle JH, Pucino F, et al. Systematic review: the effect of preventive lamivudine on hepatitis $\mathrm{B}$ reactivation during chemotherapy. Ann Intern Med 2008;148:519-528.

24. Gower E, Estes C, Blach S, RazaviShearer K, Razavi H. Global epidemiology and genotype distribution of the hepatitis $\mathrm{C}$ virus infection. J Hepatol. 2014;61(suppl 1):S45-S57.

25. Mohd Hanafiah K, Groeger J, Flaxman AD, Wiersma ST. Global epidemiology of hepatitis $\mathrm{C}$ virus infection: new estimates of age-specific antibody to $\mathrm{HCV}$ seroprevalence. Hepatology. 2013;57: 1333-1342. 
26. Sievert W, Altraif I, Razavi HA, et al. A systematic review of hepatitis $\mathrm{C}$ virus epidemiology in Asia, Australia and Egypt Liver Int. 2011;31(suppl 2):61-80.

27. Stanaway JD, Flaxman AD, Naghavi M, et al. The global burden of viral hepatitis from 1990 to 2013: findings from the Global Burden of Disease Study 2013. Lancet. 2016;388:1081-1088.

28. Torres HA, Mahale P, Blechacz B, et al.Effect of hepatitis $\mathrm{C}$ virus infection inpatients with cancer: addressing a neglected population. J Natl Compr Canc Netw. 2015;13:41-50.

29. Torres HA, Economides MP, Kyvernitakis $A$, et al. Sofosbuvir-based therapy in patients with chronic hepatitis $\mathrm{C}$ virus infection and malignancies - a prospective observational study of 143 patients. The 53rd Annual Meeting of American Society of Clinical Oncology (ASCO), June 26,2017. Chicago, IL. Abstract e18152.

30. Silvestri F, Pipan C, Barillari G, et al. Prevalence of hepatitis $C$ virus infection in patients with lymphoproliferative disorders. Blood. 1996;87:4296-4301.

31. Oguz A, Aykas F, Unal D, et al. Hepatitis $\mathrm{B}$ and $\mathrm{C}$ seroprevalence in solid tumorsnecessity for screening during chemotherapy. Asian Pac J Cancer Prev. 2014;15:1411-1414.

32. Alborino F, Burighel A, Tiller FW, et al. Multicenter evaluation of a fully automated third-eneration anti-HCV antibody screening test with excellent sensitivity and specificity. Med Microbiol Immunol 2000; 200:77-83.

33. Chevaliez S, Rodriguez C, Pawlotsky JM. New virologic tools for management of chronic hepatitis $\mathrm{B}$ and $\mathrm{C}$. Gastroenterology 2012; 142:1303-13 e1. 